\title{
Effects of Climate-Induced Changes in Parasitism, Predation and Predator-Predator Interactions on Reproduction and Survival of an Arctic Marine Bird
}

\author{
ANTHONY J. GASTON ${ }^{1}$ and KYLE H. ELLIOTT ${ }^{2}$
}

(Received 21 February 2012; accepted in revised form 4 July 2012)

\begin{abstract}
A detailed understanding of the processes and interactions within biological communities is needed to describe and predict the biological consequences of climate change. Global warming may affect biological communities at specific sites through changes in the species composition that follow changes in range, or through altered food web interactions caused by changes in phenology or behaviour. We describe the demographic consequences for a colonial nesting seabird, the Thickbilled Murre (Uria lomvia), of exceptionally intense mosquito parasitism and predation by polar bears in a particular year. Increases in mosquito parasitism and bear predation are changes in behaviour rather than changes in range, and both caused unusual adult mortality and reproductive failure in Thick-billed Murres. In the case of adult mortality, the effects of predation and parasitism were complementary, whereas in the case of reproductive failure, most birds affected by parasitism would in any case have subsequently lost their eggs to bear predation. The mosquito and bear activities had the secondary result of redirecting the attention of gulls and foxes, the usual predators of murre eggs, towards scavenging carcasses and preying on eggs exposed by birds deserting their ledges. This diversion reduced the impact of gulls and foxes on the murres and altered the spatial configuration of predation risk. Our observations emphasize the difficulty faced by ecologists in predicting the consequences of global warming even for simple and relatively well-studied ecosystems. Moreover, the net effect of combined parasitism and predation was much greater than reported previously, reducing overall colony productivity by $20 \%$ and increasing adult mortality by $20 \%$. If this effect happens every year, it will have population consequences.
\end{abstract}

Key words: murre, Uria lomvia, polar bear, parasitism, predation, food-web complexity, unpredictability

RÉSUMÉ. Il y a lieu de bien comprendre les processus et les interactions qui se produisent au sein des communautés biologiques afin d'être en mesure de décrire et de prévoir les conséquences biologiques du changement climatique. Le réchauffement climatique peut avoir des incidences sur les communautés biologiques de sites spécifiques en ce sens que la composition des espèces peut être modifiée en raison de changements caractérisant le parcours naturel ou en encore, en raison d'interactions altérées à l'échelle du réseau alimentaire attribuables à des changements de phénologie ou de comportement. Nous décrivons les conséquences démographiques relatives à un oiseau de mer colonial en nidification, soit le guillemot de Brünnich (Uria lomvia), de même que les conséquences du parasitisme exceptionnellement intense des moustiques et de la prédation par les ours polaires au cours d'une année donnée. L'intensification du parasitisme des moustiques de même que la prédation par les ours correspondent à des changements de comportement plutôt qu'à des changements de parcours, et ces deux facteurs ont causé une mortalité inhabituellement élevée chez les adultes ainsi qu'une infécondité chez le guillemot de Brünnich. En matière de mortalité chez les adultes, les effets de la prédation et du parasitisme étaient complémentaires, tandis qu'en matière d'infécondité, la plupart des oiseaux touchés par le parasitisme auraient tout de même fini par perdre leurs œufs en raison de la prédation par les ours. L'activité des moustiques et des ours a eu pour résultat secondaire de réorienter l'attention des goélands et des renards, qui sont les prédateurs habituels des œufs de guillemot, vers la charogne des carcasses et la prédation des œufs exposés par les oiseaux qui désertaient leurs corniches. Cette diversion a eu pour effet d'atténuer l'incidence des goélands et des renards sur les guillemots, en plus de modifier la configuration spatiale du risque de prédation. Nos observations font ressortir la difficulté à laquelle font face les écologistes en matière de prévision des conséquences du réchauffement climatique, même dans le cas d'écosystèmes simples et relativement bien étudiés. Par ailleurs, l'effet final du parasitisme et de la prédation mis ensemble était beaucoup plus grand que ce qui n'avait déjà été signalé, ce qui a eu pour effet de réduire la productivité générale de la colonie de 20 pour cent et d'accroître le taux de mortalité chez les adultes dans une mesure de 20 pour cent. Si cet effet se répétait chaque année, il aurait des conséquences sur la population.

Mots clés : guillemot, Uria lomvia, ours polaire, parasitisme, prédation, complexité du réseau alimentaire, imprévisibilité

Traduit pour la revue Arctic par Nicole Giguère.

\footnotetext{
${ }^{1}$ Environment Canada, National Wildlife Research Centre, Carleton University, 1125 Colonel By Drive, Ottawa, Ontario K1S 5B6, Canada; Tony.Gaston@ec.gc.ca

${ }^{2}$ Department of Biological Sciences, 190 Dysart Road, University of Manitoba, Winnipeg, Manitoba R3T 2N2, Canada

(C) The Arctic Institute of North America
} 


\section{INTRODUCTION}

Although the biological consequences of climate change have recently received much attention (Cheung et al., 2009; Chin et al., 2010; Ji et al., 2010; Jiguet et al., 2010; McMahon et al., 2011), they are generally acknowledged to be less predictable than the physical consequences (Hoegh-Guldberg and Bruno, 2010; Gilman et al., 2010; Clusella-Trullas et al., 2011). Predictions about the consequences of global warming for complex biological systems are likely to be fraught with great uncertainty.

Reviews of the biological consequences of climate change at high latitudes include predictions that both predation and parasitism will increase (Hueffer et al., 2011). These increases may occur through the poleward expansion of predator and parasite ranges (Thomas, 2010) or through changes in the behaviour of predators and parasites caused by increased temperature and perhaps associated with changes in phenology (Cairns et al., 2008; Both et al., 2009; Yang and Rudolph, 2010).

Northern Hudson Bay, Canada, has been subject to recent temperature increases (Galbraith and Larouche, 2011) and is situated on the borderline between Low and High Arctic regions, making it a particularly suitable area for the study of climate change effects. Their proximity to the Low/High Arctic boundary makes local ecosystems susceptible to rapid transition from food webs characteristic of the High Arctic to more Low Arctic configurations.

Previous observations of the marine bird breeding colony at Coats Island, northern Hudson Bay, have described effects on birds of both an increase in mosquito parasitism (Gaston et al., 2002) and an increase in polar bear Ursus maritimus predation (Smith et al., 2010). The principal breeding seabird species at this site is the Thick-billed Murre Uria lomvia, which lays its single egg on bare rock ledges of steep cliffs. Since the 1990s, mosquito parasitism on the Thick-billed Murres has become more intense and has been occurring 20 to 30 days earlier in the season. It affects the birds particularly in hot, still weather, when some adult birds die from a combination of dehydration and heat stress, aggravated by mosquito bites (Gaston et al., 2002). Irrespective of maximum daily temperature, mortality occurs only when mosquitoes attack the birds in large numbers and happens only at breeding sites close to the upper boundary of the colony (where mosquitoes are most prevalent), while sites lower down that are equally exposed to sunshine and reach similar temperatures suffer no mortality. Hence this mortality is directly attributable to increased mosquito parasitism. Moreover, when mosquito parasitism is intense, many birds leave the cliffs before they succumb, exposing their eggs to predation by gulls.

Simultaneously, because of the earlier disappearance of sea ice in northern Hudson Bay, polar bears have been forced to come ashore earlier and in poorer condition (Stirling et al., 1999, Regehr et al., 2007). This change has led them to exploit unusual food resources, especially birds and their eggs and nestlings (e.g., Rockwell and Gormezano, 2009; Smith et al., 2010; Rockwell et al., 2011).

We report here on recent observations of simultaneous parasitism and predation effects on breeding seabirds, including the effects of competition and commensalism among predators, as an example of interacting stressors caused by ongoing climate change. Multiple interactive climate-driven changes are likely to occur as climate change proceeds, but to date the interaction of different climateassociated factors has not been described in detail for specific ecosystems. This paper describes parasitism and predation taking place at Coats Island in the 2011 breeding season, a year of particularly high mosquito and polar bear activity at the Thick-billed Murre colony. The 2011 results are compared with those from earlier years in which parasitism and bear predation were low or absent. We analyze the direct and indirect effects of mosquito parasitism and bear predation on the murres to illustrate the interactions between regular (occurring annually) and climate-induced effects. Our results provide a striking indication of the complexity involved in predicting the biological impacts of climate change.

\section{METHODS}

The study was conducted near Cape Pembroke, Coats Island, in northern Hudson Bay. Observations were made on a sea cliff about $500 \mathrm{~m}$ long and $15-75 \mathrm{~m}$ high ("west sub-colony"; Fig. 1). Research on murre demography and feeding ecology has been ongoing at this site annually since 1984 (e.g., Gaston et al., 1994, 2009a). In 2011, biological observations were made from 12 July to 6 August. We also kept records of daily maximum and minimum temperatures, wind speed at $1800 \mathrm{~h}$, and precipitation. Weather in 2011 was compared with that of earlier years using data from Environment Canada's weather station at Coral Harbour, Nunavut, the station nearest to Coats Island.

Observations of Thick-billed Murres (approximately 20000 breeding pairs on the west sub-colony) and glaucous gulls Larus hyperboreus (16 breeding pairs) were made daily during the study period. The murres lay a single egg on a rock ledge, while the gulls build nests on grassy ledges immediately above, or adjacent to, the murre colony, laying a clutch of three eggs. The gulls, as well as Arctic foxes Alopex lagopus, are typical predators of the murres' eggs and chicks and exploit the murre colony every year (Gaston and Ouellet, 1997; Gaston et al., 2009b).

Extensive mosquito parasitism and bear predation are unusual at our colony. Death from heat and mosquitoes was first observed at Coats Island in 1997, and the worst previous event was in 1998, when two birds died on breeding plots (Gaston et al., 2002). Similarly, bear predation was observed in 2000 and 2003, but not in the 17 years prior to 2000 , and was limited to the consumption of a few hundred highly accessible eggs with no observed adult mortality (Smith et al., 2010). 


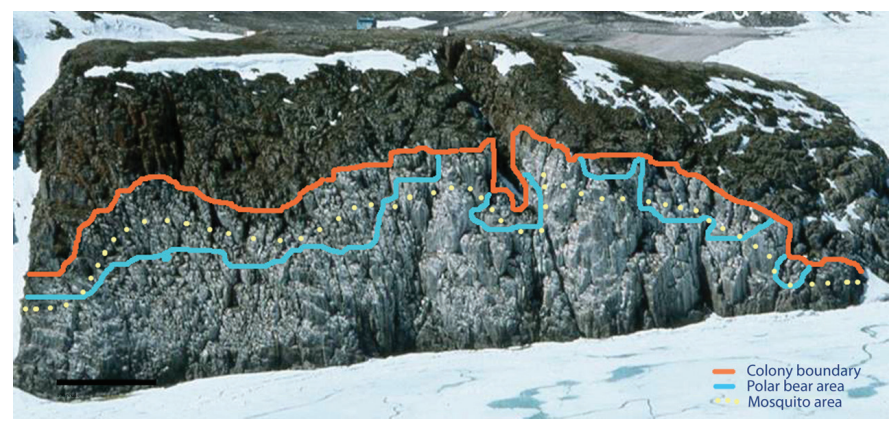

FIG. 1. The 2011 study site, viewed from out to sea. The bear and mosquito areas are bounded at the top by the colony boundary line and at the bottom by the solid and dotted lines.

In 2011, as in earlier years, we noted the numbers of birds attending different parts of the colony daily and recorded the reproductive success of murre pairs on selected study sites. At these sites, approximately 400 breeding pairs were observed for several hours daily from blinds within $20 \mathrm{~m}$ (Gaston et al., 1994). Reproductive success was estimated from the proportion of pairs assumed to have laid eggs that succeeded in rearing a nestling to the date when our observations ceased-approximately the start of chick departures at the colony. Every few days, we also surveyed the presence or absence of murre eggs and chicks on breeding ledges throughout a large part of the colony. The presence of dead birds on study plots was noted. Live adult birds were captured by noosing and weighed (on a spring balance to $\pm 10 \mathrm{~g}$ ) periodically throughout the study period. Mass was compared with that of birds weighed at similar dates during 1984-96, before any mosquito-related mortality was observed (see Gaston and Hipfner, 2006).

To provide a separate measure of physiological condition, we also measured the hematocrit of four birds a day, each held for four hours in an eight litre box within a blind on the colony cliff (for a separate project measuring metabolism and water loss). This measurement was repeated daily for 14 days at the start of the field season. From each bird, two blood samples $(50 \mu \mathrm{L}$ each) were taken by pricking the brachial vein once and collecting the blood into two hematocrit tubes, which were then spun at 5000 revolutions per minute for $8 \mathrm{~min}$. We compared those values with values obtained at the same time period in 2008 and 2009, when no mosquito-related mortality was observed. We measured temperature continuously with a Lotek 1100 temperaturedepth-time recorder (Lotek, St. John's, Newfoundland) during the four hours of captivity. Our expectation was that birds under stress would exhibit lower-than-normal hematocrit values.

The brood size of the gulls was noted every 3 to 5 days. Detailed notes were taken of the behaviour of predators, especially polar bears and glaucous gulls. We estimated losses of murre eggs and chicks to polar bear predation by mapping the areas of bear activity onto a photograph of the colony and calculating the affected area as a proportion of the total area occupied (Fig. 1). Similarly, numbers of adult birds dying as a result of mosquito parasitism were estimated by extrapolating from the affected area, assuming mortality rates observed on our study plots applied to the entire colony area within $10 \mathrm{~m}$ of the top of the occupied cliff.

Observations of hatching gave an estimated median date of hatching of 24 July, corresponding to median laying on 22 June (incubation 33 days, Gaston and Hipfner, 2000; this date is close to the average for the past 23 years). When the field crew arrived on Coats Island, incubation was about half completed and many egg losses had already taken place. It was therefore difficult to determine the number of breeding pairs present when egg laying began. Consequently, we estimated reproductive success by assuming that initial breeding numbers were equivalent to the mean for the previous four years (468 pairs; A.J. Gaston, unpubl. data). Actual numbers could have been greater, depending on the number of intermittently occupied sites used in 2011. We estimated the proportion of eggs lost because of mosquitoes from the number disappearing during peak periods of mosquito stress or on sites not accessible to bears.

Observations made in 2011 were compared to those made in previous years when similar research was conducted at Coats Island. For comparisons of reproductive success, we used the 2007-10 breeding seasons, when mosquito parasitism did not cause any desertions. Observations of polar bears ashore near the Thick-billed Murre colony on Coats Island have been noted in all years throughout the period when observers were present. To assess trends in rates of visits we calculated the number of days on which bears were seen within $1 \mathrm{~km}$ of the colony and expressed annual rates as the percentage of days on which bears were seen.

To explore the potential population impacts of the level of adult mortality and reproductive success observed at Coats Island in 2011, we developed a simple deterministic population model constructed in Excel. Given conditions of no bear predation or mosquito effects, the model assumed adult annual survival of 0.9 (Smith and Gaston, 2012; K.H. Elliott, unpubl. data) and survival to age of first breeding (fecundity) of 0.208 (the value giving a stable population).

\section{RESULTS}

\section{Parasitism}

In 2011, we observed many dead birds on the cliffs when we arrived at the colony. At that time, the most experienced observer (K.H. Elliott) considered that the density of mosquitoes was the greatest he had seen in 10 years of visits. On our study plots, we observed a minimum of 22 carcasses out of 878 breeding birds (2.5\%). Five additional deaths took place on 23-24 July, when maximum temperatures exceeded $20^{\circ} \mathrm{C}$ and parasitism was high (many mosquitoes on birds' feet and tarsi, where birds increase peripheral circulation to improve cooling; Steen and Steen, 1965). In previous years, such in situ deaths had occurred only in 


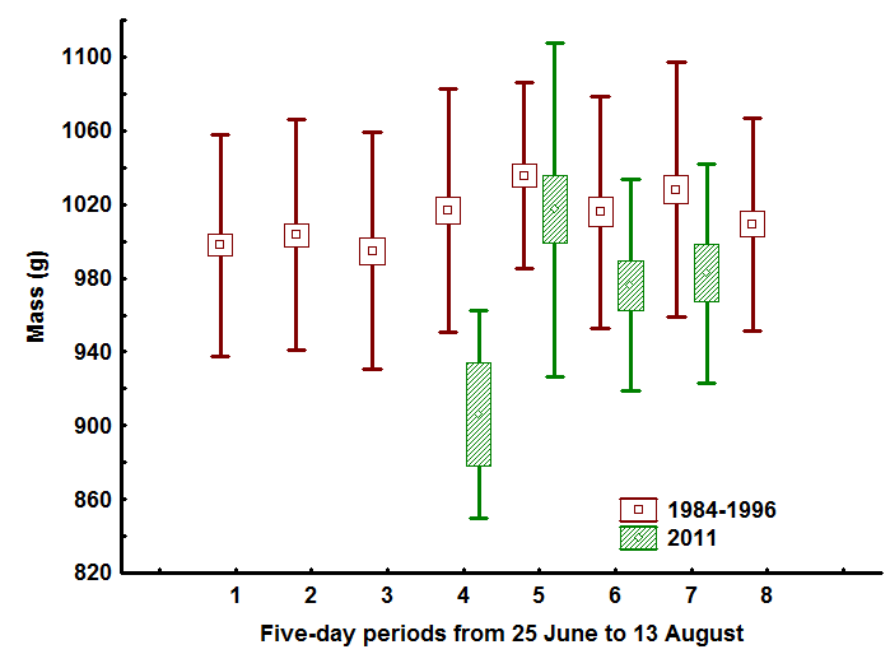

FIG. 2. Changes in the mean mass of adult murres trapped while incubating in 2011 and in 1984-96.

association with heavy mosquito parasitism (Gaston et al., 2002; A.J. Gaston, unpubl. data). A minimum of 25 additional deaths were observed elsewhere on the colony, but the total number of deaths was probably higher: our observations covered only a small part of the mosquito-affected zone, as large parts of the colony were not visible from the cliff top.

As seen previously (Gaston et al., 2002), most deaths took place near the upper boundary of the murre colony, closest to the vegetation from which the mosquitoes emerged. Observed mortality extended at least $12 \mathrm{~m}$ below the top of the colony. Extrapolating the number of deaths on our study plots to numbers of birds in the top $10 \mathrm{~m}$ of the colony, we estimated that mosquitoes caused the death of a minimum of 250 breeding adults, or $0.6 \%$ of the breeding population. Among 10 banded carcasses retrieved, five were of known age: 19, 20, 21, and 23 (two birds) years old. In contrast, less than $20 \%$ of 146 known-age adults observed at the colony in 2011 were over 18 years of age (Fisher's exact test of the difference in age distribution between those found dead and those observed alive $p<0.00001$ ). Old birds are more reluctant to leave their eggs (average time to capture by researchers is $10 \pm 8 \mathrm{~s}$ for birds over 18 years compared to $45 \pm 56 \mathrm{~s}$ for birds under 18 years) and are quicker to return to their eggs following a disturbance (average return time after being held for $10 \mathrm{~min}$ is $0.5 \pm 0.7 \mathrm{~min}$ for birds $>18$ years and $6.6 \pm$ 7.2 min for birds $<18$ year; K.H. Elliott, unpubl. data).

Carcasses were fresh on 13 July, suggesting many deaths within 48 hours. Coral Harbour (the closest weather station, $120 \mathrm{~km}$ northwest of the camp) recorded a maximum temperature of $21.4^{\circ} \mathrm{C}$ on $11 \mathrm{July}, 10^{\circ} \mathrm{C}$ above the seasonal norm (Environment Canada, 2012a). Higher temperatures occurred on 23-24 July, with maxima of $24.1^{\circ} \mathrm{C}$ and $22.5^{\circ} \mathrm{C}$ at Coral Harbour and $21.3^{\circ}$ and $21.2^{\circ} \mathrm{C}$ at our camp. Further adult mortality occurred then, but by that date most pairs on affected parts of the colony had lost their eggs, so there was no reason for birds to prolong their occupation of breeding sites.
When compared over the period 10-25 July, mass of incubating adults was consistently lower in 2011 than in earlier years (Fig. 2; ANOVA $F_{1,2}=11.6, p<0.001$ ), especially during the period 14-15 July (Fig. 2, period 4). By the chick-rearing period, however, this difference in mass had reversed: during 26 July to 4 August, adults engaged in chick-rearing were significantly heavier in 2011 than in earlier years $\left(1000 \pm 65[\mathrm{SD}] \mathrm{g}\right.$ vs $977 \pm 63 \mathrm{~g}, \mathrm{t}_{252}=2.42$, $p=0.016$ ). During incubation, hematocrit values averaged $40.0 \pm 1.3$, while by chick-rearing (when temperatures had returned to typical [lower] levels), values averaged $47.7 \pm$ 0.2 . In contrast, in the only past years when hematocrit was measured, values were similar during incubation and chick-rearing (2008 - incubation: $47.6 \pm 1.2$; chick-rearing: $46.2 \pm 1.4 ; 2009$-incubation: $48.1 \pm 1.0$ chick-rearing: 47.8 \pm 0.8 ). In 2011, hematocrit values during incubation were significantly lower for birds when ambient temperature was above $17^{\circ} \mathrm{C}(35.4 \pm 2.9)$ than when ambient temperature was below $17^{\circ} \mathrm{C}\left(41.3 \pm 1.3, \mathrm{t}_{33}=2.25, p=0.03\right)$.

Many birds deserted their eggs during peak periods of mosquito attacks, and many eggs exposed in this way were taken by predatory glaucous gulls. Among those remaining, few hatched, presumably because exposure to direct sunlight caused embryo death: out of 32 eggs not depredated but left exposed on at least one day, only one hatched, and only three other eggs were still present at the end of our study (minimum mortality $88 \%$ ), compared to $2 \%$ nonhatching $(\mathrm{N}=197)$ for eggs incubated continuously during 2007-10 on the same plot. Losses were high at two plots on the uppermost part of the colony (plots D and DA, which were too vertical to allow predation by bears), resulting in an aggregate reproductive success of only $13 \%(\mathrm{~N}=175)$, compared with typical success of $50 \%$ to $63 \%$ (Table 1). Extrapolating the observed egg losses to the top $15 \mathrm{~m}$ of the colony (Fig. 1), we estimated mosquito parasitism caused the loss of a minimum of $30 \%$ of eggs present on the colony at the time and the failure of $20 \%$ of pairs (assuming that, in the absence of mosquitoes, $33 \%$ of pairs would have lost their eggs to other causes; A.J. Gaston, unpubl. data; Fig. 3). These estimates are much higher than previously recorded at Coats Island (Table 1; Gaston et al., 2002, and unpubl. data).

\section{Bear Predation}

A polar bear was noted on the colony as the field crew arrived on 12 July, and predation of adult murres, their eggs, and nestlings by polar bears was observed daily throughout the study period. Up to four bears were seen in the vicinity of the colony on any one day, and at least two were present on the cliffs from time to time. One small male bear, identifiable from its shape and behaviour, was present throughout the period of observations. For personal safety reasons we took periodic measures to discourage bears in the vicinity of the colony, so predation probably was lower than might otherwise have been the case had we not been there. 
TABLE 1. Comparison of numbers of murre eggs laid on, numbers of chicks departing from, and reproductive success (RS) at five study plots on Coats Island in the 2007-10 breeding seasons combined and in 2011. Numbers departing in 2011 are minimum estimates based on survival to the date on which observations ended.

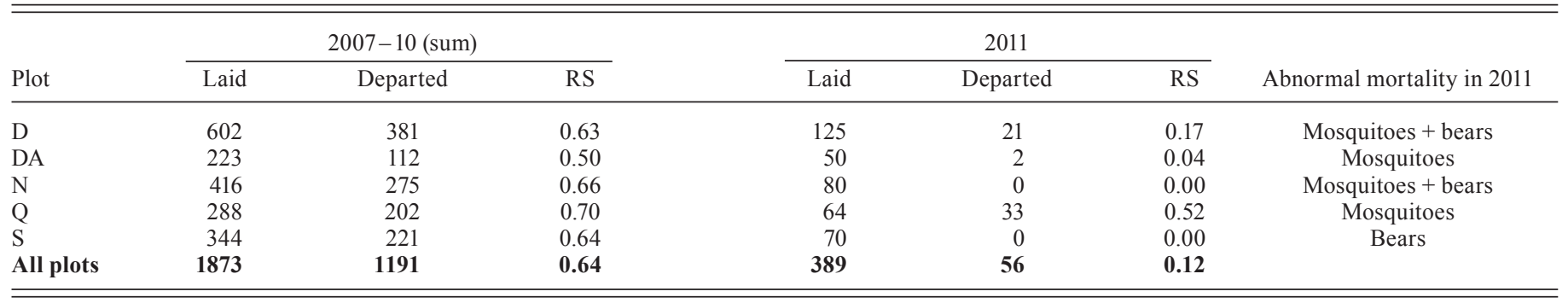

Bears initially exploited murres near the upper boundary of the colony but moved down the cliff progressively as upper areas were cleared of eggs and chicks, making use of ledges as small as $40 \mathrm{~cm}$ in width. All eggs and chicks on ledges accessed by bears were killed or dislodged, including all those on our study plots $\mathrm{N}$ and $\mathrm{S}$, which between them support a mean of 170 breeding pairs in a typical year (Table 1). Bears were active throughout the day, but especially at night, when most birds on the cliffs are female, whereas mortality from mosquitoes occurred in the middle of the day, when most birds present are male (Elliott et al., 2010). Bear activity caused mass panics of adult murres, which left the cliffs in large flocks as bears approached. Once many birds had lost their eggs or chicks, such panics became larger and more frequent, involving many hundreds of birds, as fewer birds had anything to protect. It is likely that some eggs were lost when incubating birds joined the general panic. Such losses also affected ledges inaccessible to bears. We had not observed such panics in earlier years.

Because the effect of bears was confined to ledges accessible to them, some study plots experienced total reproductive failure, whereas others were affected only by mosquitoes, depending on site topography. Sites low down on the cliff remained unaffected by either problem (Fig. 1). Only $12 \%$ of pairs breeding on regularly monitored sites (D, DA, N, Q, and S, all in the top half of the cliff) succeeded in rearing chicks to 8 August, the date on which observations ceased. This percentage is approximately onefifth of the mean annual production over the previous four years (Table 1).

We estimated that bear predation eliminated murre reproduction on $30 \%$ of the colony area (Fig. 3). Some areas affected by bears had already suffered losses as a result of mosquito parasitism. It is likely that some eggs eaten by bears would not have hatched because of previous exposure. Many partial and complete carcasses were found after the bears had moved on, indicating that only a proportion of chicks were eaten. On one study plot where chicks had been previously banded, we found six chicks dead but untouched out of 11 that disappeared after a bear visited the area. We observed few instances of replacement egg-laying on areas affected by bears, possibly because of continuous disturbance by the bears.

Polar bears also killed adults, presumably mostly breeders, as these birds are less likely to flush than non-breeders.

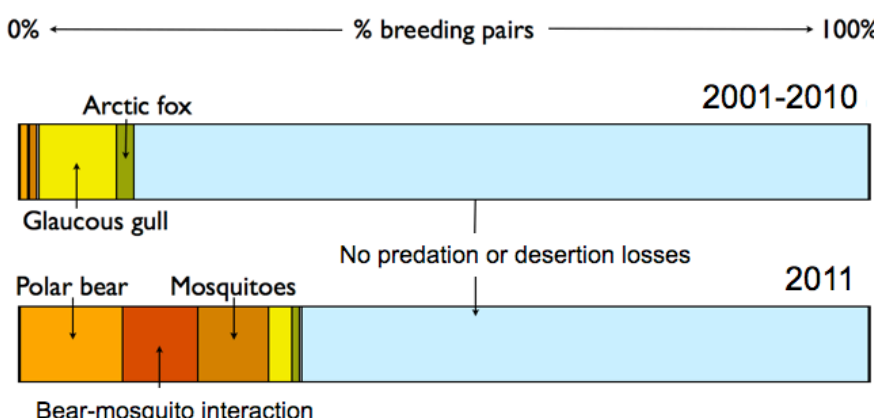

FIG. 3. Proportion of breeding pairs failing to reproduce because of predation or parasitism in 2001-10 (mean of annual rates) and in 2011. Estimates of bear and mosquito effects are based on the area of the colony affected.

Some of those killed were eaten, but like the chicks, many were left uneaten or only partially consumed: some were carried to grassy areas on the periphery of the colony, where they were accessible to foxes. We could not obtain a systematic estimate of adult losses to bear predation because carcasses were often consumed or knocked off the cliffs and some parts of the cliff could not be observed from our observation points, precluding observation of the exact number killed. Nonetheless, during 90 min of unobscured observation over three days, we observed one adult killed every $10 \mathrm{~min}$. Given that we observed a bear on the cliffs for approximately $20 \mathrm{~h}$ in aggregate, but that we were watching for less than half the time when bears might have been present, and on the basis of carcasses found, it is likely that 200 to 500 adults were killed $(0.5 \%-1.25 \%$ of the breeding population).

In addition to killing murres, the bears also killed nestling glaucous gulls. From nestling carcasses found in areas frequented by bears, we estimate that bears accounted for the loss of at least 12 out of 22 gull nestlings (55\%). Overall reproductive success was 0.6 chicks per pair, compared with a minimum of 0.9 and a mean of $1.6 \pm 0.1$ (SD) during 1990-2007 (Gaston et al., 2009b). No gull nestlings were seen to be eaten: they were killed by bites to the head, and the carcasses were left intact.

\section{Gull Predation}

Glaucous gulls actively followed the progress of feeding polar bears within the colony, taking advantage of the 


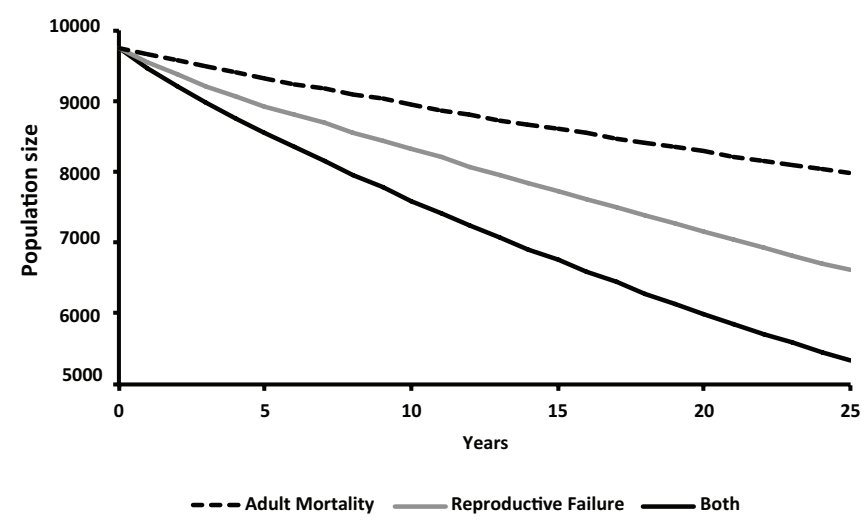

FIG. 4. Estimates of future population trends based on three scenarios: adult mortality augmented by polar bear predation and mosquito parasitism as estimated in 2011; reproductive failure caused by polar bears and mosquitos as estimated in 2011; both adult mortality and reproductive failure as seen in 2011. In the absence of either polar bear or mosquito effects, the model is adjusted to yield a constant population size.

disturbance to the murres to snatch eggs or chicks abandoned by their parents. At least one gull was invariably present with a bear as it foraged. There would also have been ample opportunity to scavenge carcasses left by the bears, although we cannot estimate how much use was made of this resource. Little active foraging by gulls was seen in the absence of bears, suggesting that most food obtained by gulls after our arrival in 2011 was available as a result of bear activity, and that gulls therefore caused little additional mortality to the murre population after the start of bear predation. Assuming that the food requirements of growing gull chicks are similar to those of adult gulls, bear predation would have reduced gull food requirements by $28 \%$ (1-(2 adults +1.6 chicks $) /(2$ adults +0.6 chicks $))$, causing a corresponding reduction in the rate of predation by gulls on murres.

\section{Population Effects}

Mortality and reproductive failure of murres caused by either mosquitoes or bears in 2011 were more than an order of magnitude higher than those seen in any of the previous 30 years. We estimate that mosquitoes killed $0.6 \%$ of breeding murres and caused the failure of $20 \%$ of breeding attempts, while bears killed $0.5 \%-1.25 \%$ of breeding murres and caused the failure of $\sim 30 \%$ of breeding attempts. Our population model predicted that, assuming no density-dependent adjustments, the persistence of 2011 conditions would produce a decrease of nearly $50 \%$ in the size of the Coats Island colony over 25 years (Fig. 4) compared with a stable population under normal conditions.

\section{DISCUSSION}

Adult mortality caused by mosquitoes and by polar bears affected different sections of the population. The combined mortality amounted to approximately $2 \%$ of the

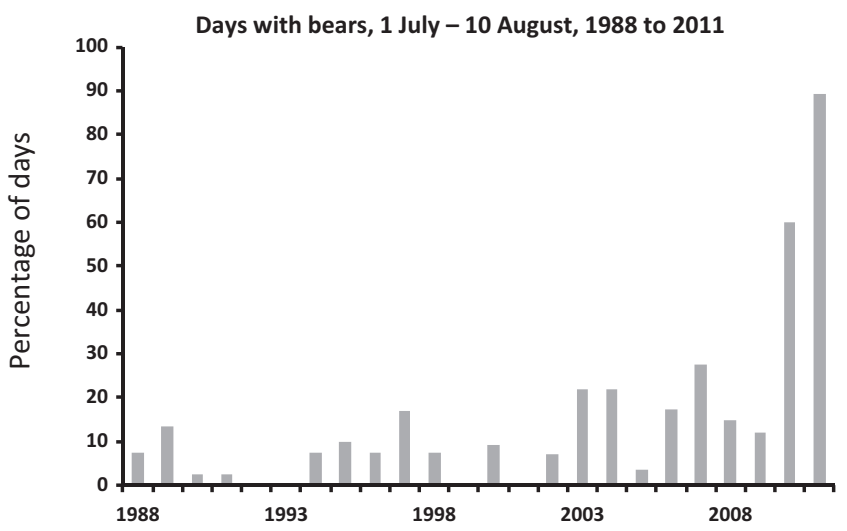

FIG. 5. Percentage of days during 10 July-20 August on which one or more polar bears were recorded on land within $1 \mathrm{~km}$ of the Coats Island Thickbilled Murre colony, or in the water at the foot of the cliffs. Not all records represent different animals.

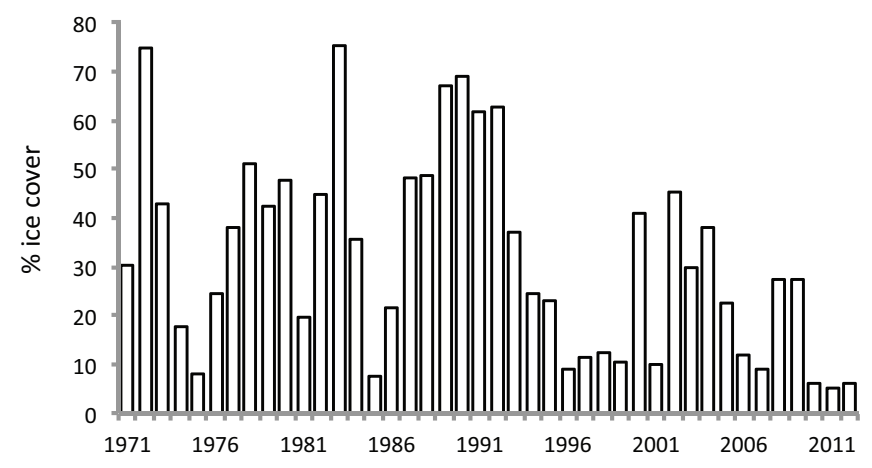

FIG. 6. Percentage ice cover in the NE quadrant of Hudson Bay (North Hudson Bay Narrows) on 9 July since 1971. Data obtained from the Canadian Ice Service of Environment Canada using their "Icegraph 2.0" tool (Environment Canada, 2012b).

adult population, all of them presumably breeding birds, or approximately $20 \%$ of average annual adult mortality $(10 \%$; Gaston et al., 1994; Wiese et al., 2004). In contrast, most areas where reproductive success was affected by mosquitoes ( $\sim 30 \%$ of the colony) subsequently were completely cleared by bears (Fig. 1), so the effect of mosquitoes on reproduction was much less than it would have been in the absence of bears (Fig. 3). Loss of eggs from gulls and bears would have reduced subsequent adult mortality from mosquitoes, as birds without eggs would have had no reason to remain on the cliffs once mosquito attacks began to stress them.

It is likely that both increased predation and increased parasitism are closely tied to warming trends in the Hudson Bay region. Bears have been seen ashore earlier and in greater numbers in recent years, presumably because of the earlier clearance of sea ice in the region (Regehr et al., 2007; Smith et al., 2010; Tivy et al., 2011; Fig. 5). Ice extent in northeast Hudson Bay on 9 July, just before we arrived at Coats Island, was the lowest on record ( $5 \%$ compared with 1971-2010 average of 28\%; Fig. 6), presumably accounting for the unusually high amount of polar bear activity in 2011. We can only speculate about the cause of very high mosquito parasitism in 2011, but it is striking that 2011 was 


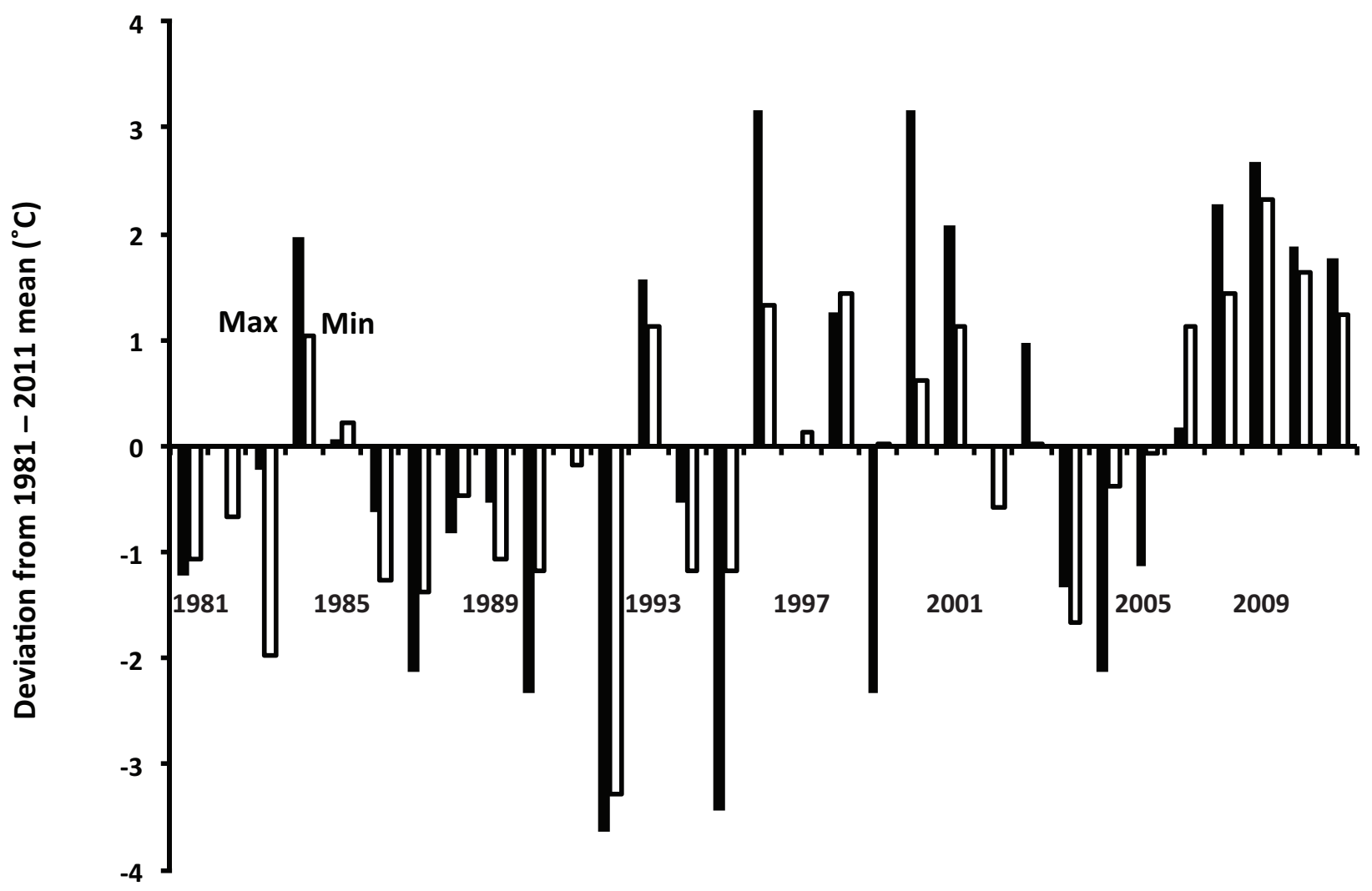

FIG. 7. Mean minimum and maximum July temperatures at Coral Harbour since 1981, obtained from Environment Canada (2012a). The records show an exceptional run of warm temperatures in the region during the past four years.

the fourth year in a row with mean maximum July temperatures at Coral Harbour, Nunavut, more than $1^{\circ} \mathrm{C}$ above the average for 1981-2010 (Fig. 7). Possibly a succession of warm summers led to a build-up in the local mosquito population.

Most of the birds killed by bears were probably experienced breeders, as old birds made up a much greater proportion of carcasses than of the general population. In addition, a single bird of known age, which died from mosquito attacks in 1998, was at least 17 years old (Gaston et al., 2002). All the evidence suggests that old birds are much less likely than young birds to desert offspring in response to a challenge (predator, parasitism, reduced foraging). Consequently, both mosquitoes and bears are more likely to kill old breeders than younger birds, with potential consequences for the age structure of the population.

Incubating birds were much lighter in 2011 than at similar dates in years before any mosquito effects were observed, suggesting that their energy reserves were affected during this period. Similarly, the birds had very low hematocrit, a measure of physiological condition. However, the fact that body mass rebounded within 10 days, so that it was higher than normal during chick-rearing, suggests that the low body weights were not caused by an inadequate food supply, but were the direct result of stress brought on by mosquito attacks. Part of the mass loss may have been caused by dehydration. For instance, the low hematocrit may have been partly due to increased water movement to the extremities to combat overheating. Likewise, measurements of water loss in captive murres held between $8^{\circ}$ and $22^{\circ} \mathrm{C}$, but with mosquitoes excluded, showed constant water loss rates (and metabolic rates) between $8^{\circ}$ and $17^{\circ} \mathrm{C}$ and higher rates of water loss (and metabolic rate) above $17^{\circ} \mathrm{C}\left(\mathrm{t}_{37}=4.17, p=0.0001\right)$, peaking at $3.5 \mathrm{~g} / \mathrm{h}$ of water loss at $22^{\circ} \mathrm{C}$ (part of a separate project, K.H. Elliott, unpubl. data). The exact role of dehydration through evaporative cooling compared with reaction to mosquito bites cannot be determined from our data, but the absence of mortality on days when mosquitoes were not abundant suggests that most mortality observed was due to mosquito parasitism rather than caused by dehydration consequent on temperature alone.

Gulls typically patrol the breeding cliffs and snatch unguarded murre eggs and chicks or actively drag adult murres from their ledges to take eggs (Gilchrist et al., 1998). No estimate of total gull predation has been made at Coats Island, but at the nearest murre colony, at Digges Island, Nunavut, gulls caused $\sim 10 \%$ of breeding failures (Gaston et al., 1985). Because polar bears carried out excess killing of birds, numerous carcasses and partial carcasses were available for other predators or scavengers. Most independent predation by gulls and foxes ceased, and while gulls concentrated on areas where murres deserted their eggs because of mosquitoes or were scared off by bears, foxes scavenged on partially eaten polar bear kills. Consequently, in 2011, we expect that murres on lower sections of 
the cliffs, not affected by mosquitoes or accessed by bears, would have experienced lower than normal predation by gulls. Probably most eggs taken by gulls would otherwise have been consumed by bears. Predation by Arctic foxes was impossible to estimate because they were most active at night. However, given that no eggs or chicks remained on fox-accessible murre ledges by August, and given the large number of carcasses left by the bears, it seems probable that the foxes took fewer eggs and chicks in 2011 than in earlier years because of the opportunities to scavenge polar bear kills, which they were seen to do.

When both predation and parasitism increase simultaneously, the outcome will depend on the accessibility and size of the colony: at Coats Island most reduction in reproductive success caused by mosquitoes would have occurred anyway through bear predation, but at a colony with different topography, the interaction could have been different. At the same time, both bears and mosquitoes created conditions that enabled scavenging by gulls and foxes, reducing the need for those predators to resort to direct predation. In addition, redirecting gull predation towards scavenging altered the relative value of different breeding sites, reducing the value of sites high on the cliff while presumably increasing the value of those lower down. If the predation and parasitism seen in 2011 persist in future years, we can anticipate a general shift by the murres towards breeding sites on lower and steeper sections of cliff that are inaccessible to bears.

Our results demonstrate the potentially catastrophic effect of combined increased predation and parasitism at a seabird colony. Early arrival of polar bears at the seabird breeding colony in 2011 caused overlap between terrestrial foraging by bears and the breeding season of the murres. The situation we describe was probably a consequence of early ice break-up, which drove bears ashore earlier than usual (Regehr et al., 2007), combined with inflexible phenology of the murres (Gaston et al., 2009a) so that the bears arrived at the colony in the middle of breeding. The resulting coincidence between predator activity and prey breeding did not support the prediction of Both et al. (2009), who suggested that higher trophic levels would respond more slowly to climate change than lower levels. Whereas some authors have suggested that range shifts and population-level effects of climate change will occur through a changing thermal niche (McMahon and Hays, 2006; Porter and Kearney, 2009), our results suggest that the biological effects of parasites and predators will have a substantial impact on Arctic-breeding murre populations before any physiological threshold is reached.

Probably similar instances of multiple climate change effects and interactions will occur at other sites. Predicting their net impact will be difficult unless all sources of mortality can be accounted for. The outcome may be very different in situations that differ only in minor aspects of topography. The complexity of the interactions described here, even in a comparatively simple food web, such as the Coats Island murre colony, illustrates the difficulty researchers will experience in predicting future climate change effects.

\section{ACKNOWLEDGEMENTS}

We thank our field companions in 2011, Siasi Alogut, Ashleigh Westphal, Edith Grosbellet, Josiah Nakoolak, and Orla Osborne, for their fortitude in a difficult season and Jason Akearok and Mark Mallory of Canadian Wildlife Service, Rick Armstrong of Nunavut Research Institute, the pilots of Ken Borek Air Services, and Christine Eberl of Environment Canada for assistance with logistics. Financial support came from Environment Canada, the Northern Scientific Training Program, the Natural Sciences and Engineering Research Council of Canada (NSERC), the Polar Continental Shelf Project of Natural Resources Canada, and the Northern Contaminants Program of Aboriginal Affairs and Northern Development Canada. K.H. Elliott was supported by an NSERC Vanier Scholarship, a Garfield Weston Northern Studies Award, a Jennifer Robinson Scholarship from the Arctic Institute of North America, a Sigma Xi Research Grant, an Animal Behaviour Society Research Grant, and Northern Studies Training Program support through the University of Manitoba. An earlier draft of this paper was commented on by Sam Iverson, Evan Richardson, Paul Smith, and Ian Stirling.

\section{REFERENCES}

Both, C., van Asch, M., Bijlsma, R.G., van den Burg, A.B., and Visser, M.E. 2009. Climate change and unequal phenological changes across four trophic levels: Constraints or adaptations? Journal of Animal Ecology 78(1):73-83.

Cairns, D.K., Gaston, A.J., and Huettmann, F. 2008. Endothermy, ectothermy and the global structure of marine communities. Marine Ecology Progress Series 356:239-250.

Cheung, W.W.L., Lam, V.W.Y., Sarmiento, J.L., Kearney, K., Watson, R., and Pauly, D. 2009. Projecting global marine biodiversity impacts under climate change scenarios. Fish and Fisheries 10(3):235-251.

Chin, A., Kyne, P.M., Walker, T.I., and McAuley, R.B. 2010. An integrated risk assessment for climate change: Analysing the vulnerability of sharks and rays on Australia's Great Barrier Reef. Global Change Biology 16(7):1936-1953.

Clusella-Trullas, S., Blackburn, T.M., and Chown, S.L. 2011. Climatic predictors of temperature performance curve parameters in ectotherms imply complex responses to climate change. American Naturalist 177(6):738-751.

Elliott, K.H., Gaston, A.J., and Crump, D. 2010. Sex-specific behavior by a monomorphic seabird represents risk partitioning. Behavioral Ecology 21(5):1024-1032.

Environment Canada. 2012a. Canadian daily climate data. National Climate Data and Information Archive. <http:// climate.weatheroffice.gc.ca/prods_servs/index_e.html\#cdcd $>$. - 2012b. IceGraph 2.0.4 - Tool. http://dynaweb.cis.ec.gc.ca/ IceGraph20. 
Galbraith, P.S., and Larouche, P. 2011. Sea-surface temperature in Hudson Bay and Hudson Strait in relation to air temperature and ice cover breakup, 1985-2009. Journal of Marine Systems $87: 66-78$.

Gaston, A.J., and Hipfner, J.M. 2000. Thick-billed Murre Uria lomvia. In: Poole, A., and Gill, F., eds. The birds of North America 497. Philadephia: The Birds of North America, Inc.

2006. Adult Brunnich's Guillemots Uria lomvia balance body condition and investment in chick growth. Ibis 148(1):106-113.

Gaston, A.J., and Ouellet, H. 1997. Birds and mammals of Coats Island, N.W.T. Arctic 50(2):101-118.

Gaston, A.J., Cairns, D.K., Elliot, R.D., and Noble, D.G. 1985. A natural history of Digges Sound. Canadian Wildlife Service Report Series 46.63 p.

Gaston, A.J., de Forest, L.N., Donaldson, G., and Noble, D.G. 1994. Population parameters of Thick-billed Murres at Coats Island, Northwest Territories, Canada. The Condor 96(4):935-948.

Gaston, A.J., Hipfner, J.M., and Campbell, D. 2002. Heat and mosquitoes cause breeding failures and adult mortality in an Arctic-nesting seabird. Ibis 144(2):185-191.

Gaston, A.J., Gilchrist, H.G., Mallory, M.L., and Smith, P.A. 2009a. Changes in seasonal events, peak food availability, and consequent breeding adjustment in a marine bird: A case of progressive mismatching. The Condor 111(1):111-119.

Gaston, A.J., Descamps, S., and Gilchrist, H.G. 2009 b. Reproduction and survival of Glaucous Gulls breeding in an Arctic seabird colony. Journal of Field Ornithology 80(2):135-145.

Gilchrist, H.G., Gaston, A.J., and Smith, J.N.M. 1998. Wind and prey nest sites as foraging constraints on an avian predator, the Glaucous Gull. Ecology 79(7):2403-2414.

Gilman, S.E., Urban, M.C., Tewksbury, J., Gilchrist, G.W., and Holt, R.D. 2010. A framework for community interactions under climate change. Trends in Ecology \& Evolution 25(6):325-331.

Hoegh-Guldberg, O., and Bruno, J.F. 2010. The impact of climate change on the world's marine ecosystems. Science 328(5985):1523-1528.

Hueffer, K., O’Hara, T.M., and Follmann, E.H. 2011. Adaptation of mammalian host-pathogen interactions in a changing Arctic environment. Acta Veterinaria Scandinavica 53:17, doi:10.1186/1751-0147-53-17.

Ji, R., Edwards, M., Mackas, D.L., Runge, J.A., and Thomas, A.C. 2010. Marine plankton phenology and life history in a changing climate: Current research and future directions. Journal of Plankton Research 32(10):1355-1368.

Jiguet, F., Gregory, R.D., Devictor, V., Green, R.E., Vorisek, P., Van Strien, A., and Couvet, D. 2010. Population trends of European common birds are predicted by characteristics of their climatic niche. Global Change Biology 16(2):497-505.
McMahon, C.R., and Hays, G.C. 2006. Thermal niche, large-scale movements and implications of climate change for a critically endangered marine vertebrate. Global Change Biology 12(7):1330 - 1338, doi:10.1111/j.1365-2486.2006.01174.x.

McMahon, S.M., Harrison, S.P., Armbruster, W.S., Bartlein, P.J., Beale, C.M., Edwards, M.E., Kattge, J., Midgley, G., Morin, X., and Prentice, I.C. 2011. Improving assessment and modelling of climate change impacts on global terrestrial biodiversity. Trends in Ecology \& Evolution 26(5):249-259.

Porter, W.P., and Kearney, M. 2009. Size, shape, and the thermal niche of endotherms. Proceedings of the National Academy of Sciences of the USA 106(Suppl. 2):19666-19672.

Regehr, E.V., Lunn, N.J., Amstrup, S.C., and Stirling, I. 2007. Effects of earlier sea ice breakup on survival and population size of polar bears in western Hudson Bay. Journal of Wildlife Management 71(8):2673-2683.

Rockwell, R.F., and Gormezano, L.J. 2009. The early bear gets the goose: Climate change, polar bears and lesser snow geese in western Hudson Bay. Polar Biology 32:539-547.

Rockwell, R.F., Gormezano, L.J., and Koons, D.N. 2011. Trophic matches and mismatches: Can polar bears reduce the abundance of nesting snow geese in western Hudson Bay? Oikos 120(5):696-709.

Smith, P.A., and Gaston, A.J. 2012. Environmental variation and the demography and diet of Thick-billed Murres. Marine Ecology Progress Series 454:237-249.

Smith, P.A., Elliott, K.H., Gaston, A.J., and Gilchrist, H.G. 2010. Has early ice clearance increased predation on breeding birds by polar bears? Polar Biology 33(8):1149-1153.

Steen, I., and Steen, J.B. 1965. The importance of the legs in the thermoregulation of birds. Acta Physiologica Scandinavica 63:285-291.

Stirling, I., Lunn, N.J., and Iacozza, J. 1999. Long-term trends in the population ecology of polar bears in western Hudson Bay in relation to climatic change. Arctic 52(3):294-306.

Thomas, C.D. 2010. Climate, climate change and range boundaries. Diversity and Distributions 16(3):488-495.

Tivy, A., Howell, S.E.L., Alt, B., McCourt, S., Chagnon, R., Crocker, G., Carrieres, T., and Yackel, J.J. 2011. Trends and variability in summer sea ice cover in the Canadian Arctic based on the Canadian Ice Service Digital Archive, 1960-2008 and 1968-2008. Journal of Geophysical Research 116, C03007, doi:10.1029/2009JC005855.

Wiese, F.K., Robertson, G.J., and Gaston, A.J. 2004. Impacts of chronic marine oil pollution and the murre hunt in Newfoundland on Thick-billed Murre Uria lomvia populations in the eastern Canadian Arctic. Biological Conservation 116(2):205-216.

Yang, L.H., and Rudolf, V.H.W. 2010. Phenology, ontogeny and the effects of climate change on the timing of species interactions. Ecology Letters 13(1):1-10, doi:10.1111/j.14610248.2009.01402.x. 